Experiments in this direction are currently under investigation in our laboratory.

Work in MH's laboratory is supported by the Austrian "Fonds zur Förderung wissenschaftlicher Forschung", by the Austrian "Nationalbank", and by the "Komission Onkologie" of the Medical Faculty of the University of Vienna. The authors wish to thank Thomas Soucek, Oliver Pusch, Gabriele Hölzl, and Elke Hengstschläger-Ottnad for helpful discussion and comments on the manuscript.

MARKUS HENGSTSCHLÄGER GERHARD BERNASCHEK University of Vienna, Obstetrics and Gynecology, Department of Prenatal Diagnosis and Therapy, Währinger Gürtel 18-20, A-1090 Vienna, Austria

1 de la Cruz F, Shifrin H, Elias S, et al. Prenatal diagnosis by use of fetal cells isolated from maternal blood. Am $\mathcal{f}$ Obstet Gynecol maternal blood

2 Adinolfi $M$. Non- or minimally invasive prenatal diagnostic tests on maternal blood samples or 96.

3 Gänshirt D, Garritsen HSP, Holzgreve W. Fetal cells in maternal blood. Curr Opin Obstet Gyne-

4 Hengstschläger $M$, Wawra E. Cytofluorometric assay for the determination of thymidine uptake and phosphorylation in living cells. Cytometry 1993;14:39-45.

5 Hengstschläger $M$, Wawra E. Cytofluorometric determination of thymidine kinase activity in a determination of thymidine kinase activity in a Cancer 1993;67:1022-5. 6 Hengstschläger $M$, Hengstschläger-Ottnad $E$, Pusch O, Wawra E. The role of p16 in the E2F-dependent thymidine
Oncogene 1996;12:1635-43.

7 Hengstschläger $M$, Pusch $O$, HengstschlägerOttnad E, Ambros PF, Bernaschek G, Wawra E. Loss of the p16/MTS1 tumor suppressor gene causes E2F-mediated deregulation of essential enzymes of the DNA precurso metabolism. DNA Cell Biol 1996;15:41-51.

8 Hengstschläger $M$, Pfeilstöcker $M$, Wawra $E$. Identification of leukemic cells in bone marrow assay. Br $\mathcal{F}$ Cancer 1996;73:1237-40.

\section{Segregation distortion of the CTG repeats at the myotonic dystrophy (DM) locus: new data from Brazilian DM families} dominant condition caused by a (CTG) expansion in the protein kinase (DMPK) gene locus on chromosome 19q. ${ }^{1-6}$ The clinical course is highly variable and may include frontal baldness, cataract, progressive muscular weakness and atrophy, male infertility, diabetes, and mental retardation. ${ }^{7}$ An intriguing question is how a disease which usually decreases reproductive fitness within a few generations has been maintained in the population with a relatively high prevalence, considering the rarity of new mutations. ${ }^{8}$ An attractive hypothesis which has been proposed to explain this observation is the occurrence of meiotic drive, ${ }^{9-11}$ that is, a sex specific distortion during meiosis (which may occur when there is a negative selection against one or more class of gametes or when transcervical cells. Prenat Diagn 1995;15:889col 1995;7:103-8. and blood samples by a new cytofluorometric

Myotonic dystrophy (DM) is an autosomal

they are unable to conjugate according to the usual meiotic pattern) favouring the transmission of larger repeat alleles. This mechanism would allow the replacement of the enlarged repeat alleles lost through negative selection, thus maintaining the prevalence of these conditions in the population.

Meiotic drive favouring the transmission of larger alleles in the DM locus through male meiosis was first suggested in 1994 for normal subjects ${ }^{9}$ and supported by Gennarelli et $a l^{10}$ in affected DM families. More recently, Chakraborty et al ${ }^{11}$ reported a preferential transmission of larger alleles in female meiosis but not in male meiosis, in contrast to the first two studies. These conflicting results show that the origin of meiotic drive is controversial.

In order to address this question, we have analysed the total number of affected versus normal subjects in 69 Brazilian families with $\mathrm{DM}$ and compared in the offspring of affected fathers versus affected mothers (1) the total proportion of affected versus norma offspring and (2) the sex ratio among affected and normal descendants.

As seen in table 1, there was no segregation distortion, that is, no significant difference in the expected mendelian ratios. The total proportion of affected versus normal offspring of maternal compared to paternal origin was 102 affected versus 107 unaffected born to DM mothers $\left(\chi^{2}=0.11, p=0.74\right)$ and 206 affected versus 200 normal born to affected fathers $\left(\chi^{2}=0.07, p=0.79\right)$. In addition, the analysis of the sex ratio showed that among the normal offspring of affected DM parents the proportion of male:female did not differ from expected ( 57 males: 50 females of maternal origin, $\chi^{2}=0.42, \quad \mathrm{p}=0.52 ; 97$ males: 103 females, $\chi^{2}=0.186, p=0.67$ )

Therefore no excess of DM patients was observed in Brazilian DM families as reported in Italian and Spanish DM pedigrees. ${ }^{10}$ One possible explanation is that in the present sample a proportion of subjects classified as normal, in particular in the older generations (and who are not available for DNA analysis), may carry the mutant allele.

However, among DM patients there were more affected male than female offspring, both of maternal ( 57 males: 45 females) and of paternal origin (117 males:89 females). This difference did not reach the level of significance $\left(\chi^{2}=1.41, p=0.24\right)$ for the offspring of affected mothers but was at the limit of significance $\left(\chi^{2}=3.80, p=0.05\right)$ for the offspring of affected fathers, probably owing to the sample size. Indeed, when the descendants of DM mothers were analysed together with those of DM fathers, the excess of affected males was statistically significant ( 174 males: 134 females, $\chi^{2}=5.19, p=0.02$ ).

These findings support the observation of Gennarelli et $a l^{10}$ who reported that the mutant allele is preferentially transmitted to sons than to daughters. Indeed, as seen in table 1 , when we analysed our data together with those published by these authors, there

Table 1 Proportion of affected and unaffected offspring born to DM parents

\begin{tabular}{|c|c|c|c|c|c|c|}
\hline \multirow{2}{*}{$\begin{array}{l}\text { Present study } \\
\left(\text { Gennarelli et al }{ }^{10}\right)\end{array}$} & \multicolumn{3}{|c|}{ DM fathers, $n=114$ (210) } & \multicolumn{3}{|c|}{ DM mothers, $n=78$ (178) } \\
\hline & $D M$ & Normal & Total & $D M$ & Normal & Total \\
\hline $\begin{array}{l}\text { Sons } \\
\text { Daughters } \\
\text { Total }\end{array}$ & $\begin{array}{r}117(166) \\
89(148) \\
206(314)\end{array}$ & $\begin{array}{r}97(105) \\
103(106) \\
200(211)\end{array}$ & $\begin{array}{l}214(271) \\
192(251) \\
406(525)\end{array}$ & $\begin{array}{c}57(112) \\
45(95) \\
102(207)\end{array}$ & $\begin{array}{c}57(71) \\
50(94) \\
107(165)\end{array}$ & $\begin{array}{r}114(183) \\
95(189) \\
209(372)\end{array}$ \\
\hline
\end{tabular}

Male DM versus normal offspring: maternal $\mathrm{p}=0.24$; paternal $\mathrm{p}=0.05$; total: maternal + paternal $\mathrm{p}=0.02$. Data from the present study are shown in bold and from Gennarelli et $a^{10}$ in parentheses. was a more significant excess of affected DM males; the total number of affected offspring (of both maternal and paternal origin) was 452 males: 377 females $\left(\chi^{2}=6.78, p=0.01\right)$. Also, in accordance with these authors, we observed that although the mutant allele is preferentially transmitted to male offspring by both sexes, the distortion reached a level of significance only in male to male transmission.

Interestingly, in a previous study of Brazilian DM families we had observed a significantly greater proportion of affected DM males than females, ${ }^{12}$ which had also been reported by others, ${ }^{13}$ a finding for which we had no biological explanation (except a bias of ascertainment). This observation was confirmed in the present study since among 878 subjects, there was a statistically significant excess of affected males as compared to affected females (237 males:174 females, $\chi^{2}=9.65, \mathrm{p}=0.002$ ), but no sex ratio distortion among unaffected relatives (234 males:233 females).

The present observation confirming that the mutant parental allele is significantly more often transmitted to sons than to daughters provides an explanation for the excess of affected males in DM families. It is noteworthy that the preferential transmission of the mutant allele to sons than to daughters independently of the sex of the transmitting parent, was also found in Brazilian MachadoJoseph disease families. ${ }^{14}$ These findings suggest that the mutated allele may have a selective advantage at the pre- or postzygotic level.

An interesting and unexpected finding is that although male infertility (but not female infertility) is one of the features reported for myotonic dystrophy, we have found in the present study that DM affected males have on average more children (406 offspring/114 fathers, mean=3.6 children per affected father) than DM mothers (209 offspring/78 mothers, mean $=2.7$ children per affected mother), although the proportion of affected patients who reproduced was similar for both sexes $(78 / 174=0.45$ females and $114 /$ $237=0.48$ males). A higher reproductive fitness in DM males (525 offspring/210 fathers, mean 2.5 child per father) than in DM females (372 offspring/178 mothers, mean 2.08 child per mother) was also reported in the study published by Gennarelli et $a .^{10}$ One possible explanation for this reproductive sex difference is that DM males are on average less severely affected than DM females. Indeed, in both studies the CTG expansion was significantly larger in the group of DM affected mothers (range from 66 to 1700 repeats in the present study, 90 to 2000 in the study of Gennarelli et $\mathrm{al}^{10}$ ) than in the group of affected fathers (ranging from 66 to 900 repeats in the present study, 54 to 1100 in the study of Gennarrelli et $a l^{10}$ ).

Interestingly, the estimated relative fitness of our DM males was also slightly greater than that observed in our normal population, as reported in the last census for the population of São Paulo (3.46 per male, age range 23-72). Therefore, it is tempting to speculate that if confirmed that DM men have a slightly higher relative fertility than the normal population associated with the observed preferential transmission of enlarged alleles to males, this would provide an explanation for maintaining the frequency of mutant alleles which are lost through negative selection. Other population studies will be very important to confirm this hypothesis. 
The possibility that the loss of mutant alleles is balanced by the transition of larger normal ones into the lower DM range, which are more frequently found in DM males, should also be considered.

Although our data are at variance with the recent report of Chakraborty et $a l^{11}$ for normal subjects, it is still unknown whether the mechanisms responsible for segregation distortion are the same for DM alleles in the normal range compared to full scale expanded ones. The preferential transmission of larger alleles could be modulated by as yet unidentified cis and trans acting genetic elements, or could be a direct consequence of the CTG repeat number, affecting gamete or zygote viability. The recent observations that the expanded allele is preferentially transmitted in male meiosis in other conditions caused by dynamic expansions, such as dentatorubral-pallidoluysian atrophy and $\mathrm{MJD},{ }^{14}{ }^{15}$ are more suggestive of a direct consequence of the CTG repeat number in these conditions, at least for full scale expanded alleles.

In summary, results from the present study confirm that the issue of meiotic drive and segregation distortion is still controversial and may vary in different populations. Further studies will be important to shed more light on this fascinating question.

We are very grateful to Dr Rita C M Pavanello and Dr Suely K Marie for clinical and neurological examinations, to Marta Canovas and Constancia Urbani for their invaluable help, and to Dr Paulo A Otto for help in the statistical analysis. The support of FAPESP, CNPq, FINEP, PRONEX, and IEAE is gratefully acknowledged.

MAYANA ZATZ ANTONIA CERQUEIRA MARIZ VAINZOF MARIA RITA PASSOS-BUENO Departamento de Biologia, Instituto de Biociências, Universidade de São Paulo, São Paulo, CEP 05508-900, Brazil

1 Aslanidis C, Jansen G, Amemiya C, et al. Cloning of the essential myotonic dystrophy region and mapping of the putative defect. Nature 1992;355:548-51.

2 Brook D, McCurrach ME, Harley HG, et al. Molecular basis of myotonic dystrophy: expansion of a trinucleotide (CTG) repeat at the 3' end of a transcript encoding a protein kinase family member. Cell 1992;68:799-808.

3 Buxton J, Shelbourne P, Davies J, et al. Detection of an unstable fragment of DNA specific to individuals with myotonic dystrophy. Nature 1992;355:547-8.

4 Fu YH, Pizzuri A, Fenwick RG Jr, et al. An unstable triplet repeat in a gene related to myotonic muscular dystrophy. Science 1992;255: tonic m.

5 Harley HG, Brook JD, Rundle SA, et al. Expansion of an unstable DNA region and phenotypic variation in myotonic dystrophy. Nature 1992;355:545-6.

6 Mahavedan M, Tsilfidis C, Sabourin L, et al. Myotonic dystrophy mutation: an unstable CTG repeat in the 3' untranslated region of the gene. Science 1992;255:1253-5.

7 Harper PS. Myotonic dystrophy. 2nd ed. London Saunders, 1989.

8 Imbert G, Kretz C, Johnson K, Mandel JL. Origin of the expansion mutation in myotonic dystrophy. Nat Genet 1993;4:72-6.

9 Carey N, Johnson K, Nokelainen $\mathrm{P}$, et al. Meiotic drive at the myotonic dystrophy locus? Nat Genet 1994;6:117-18.

10 Gennarelli M, Dallpaiccola B, Baiget M Martorell L, Novelli G. Meiotic Baiget $M$, myotonic dystrophy locus. $\mathcal{F}$ Med Genet 1994; 31:980.

11 Chakraborty R, Stivers DN, Deka R, Yu ML Shriver MD, Ferrell RE. Segregation distortion of the CTG repeat at the myotonic dystrophy of the CTG repeat at the myotonic dystrop
locus. Am $\mathcal{F}$ Hum Genet 1996;59:109-18.

12 Passos-Bueno MR, Cerqueira A, Vainzof $M$ Marie SK, Zatz M. Myotonic dystrophy: genetic, clinical, and molecular analysis of patients from 41 Brazilian families. $\mathcal{F} \mathrm{Med}$ Genet 1995;32:14-18.
13 Brunner HG, Bruggenwirth HT, Nillesen W, et al. Influence of sex of the transmitting parent as well as of parental allele size on the CTG expansion in myotonic dystrophy (DM). Am $\mathcal{F}$ Hum Genet 1993;53:1016-23.

14 Iughetti P, Marie SK, Otto PA, et al. Analysis of Machado-Joseph locus (MJD1) in Brazilian families confirms the occurrence of meiotic drive. Am $\mathcal{F}$ Med Genet (in press).

15 Ikeuchi $\mathrm{T}$, Igarashi $\mathrm{S}$, Takiyama $\mathrm{Y}$, et al. Non-Mendelian transmission in dentatorubral-pallidoluysian atrophy and Machado-Joseph disease: the mutant allele is preferentially transmitted in male meiosis. $\mathrm{Am}$ f Hum Genet 1996;58:730-3.

\section{BOOK REVIEWS}

If you wish to order or require further information regarding the titles reviewed here, please write to or telephone the BMJ Bookshop, PO Box 295, London WC1H 9JR. Tel 0171383 6244. Fax 01713836662. Books are supplied post free in the UK and for BFPO addresses. Overseas customers should add $15 \%$ for postage and packing. Payment can be made by cheque in sterling drawn on a UK bank or by credit card (Mastercard, Visa, or American Express) stating card number, expiry date, and full name. (The price and availability are occasionally subject to revision by the Publishers.)

Human Genetics-A Problem Based Approach. Bruce $\mathbf{R}$ Korf. (£19.50.) Oxford: Blackwell Science Ltd. 1996.

I have never been keen on problem based learning and I was quite sceptical when I started to read this book. The book covers most aspects of clinical genetics in 10 chapters. Each of these deals with a different aspect of genetics, such as $\mathrm{X}$ linked genetic transmission or mitochondrial inheritance, and is based around a clinical scenario. The chapter dealing with $\mathrm{X}$ linked genetic transmission, for example, goes through the features of Duchenne and Becker muscular dystrophy (DMD), dystrophin, and $\mathrm{X}$ chromosome inactivation by discussing a couple who attend a genetic clinic for counselling because the woman's half brother has DMD. This clinical scenario is taken in stages and the scientific basis for each aspect discussed. There is also a small section written by the mother of a child with DMD explaining what it is like to live with a child with DMD.

The book is clearly presented, very readable, and the numerous diagrams simple and explanatory. The conditions discussed in each chapter have been well chosen and the sections written by patients are excellent.

After reading the book I have warmed to this method of learning. The facts are more memorable because the clinical applications are clear and because they all relate back to the couple or person discussed. I am not sure who would benefit most from this book. It is probably too clinical for undergraduates but would recommend it to clinical students or clinicians wanting to learn more about genetics in practice.

DOROTHY TRUMP
Molecular Mechanisms of Dementia. Editors Wilma Wasko, Rudolph E Tanzi. (Pp 312; \$99.50.) New Jersey: Humana Press. 1997. ISBN 0-896-03371-6.

This book describes molecular processes associated with dementia and is directed at scientists interested in the field. The molecular slant will decrease its appeal for most geriatric psychiatrists and geriatricians.

The 18 chapters consider a wide variety of processes which may be involved in the pathology of Alzheimer's disease and other dementias, ranging from genes involved in early onset familial Alzheimer's disease and a review of possible biological roles of apo $E$ to discussions of $\beta$-amyloid metabolism, tau, energy metabolism, apoptosis, free radicals, inflammatory mediators, zinc metabolism, and transgenic approaches. There are also chapters on vascular dementia, Pick disease, and prion diseases. The editors and the authors are well respected workers in the field.

After reading the book, I felt slightly overwhelmed by the many possible mechanisms which can account for aspects of Alzheimer's disease pathology, which are supported to various degrees by experimental data. I found the breadth of approaches stimulating and was impressed by the well balanced arguments and lack of dogma. In general, the chapters are well written and scientifically detailed. Referencing is comprehensive. Appropriate diagrams and tables are provided.

One of the possible hazards of producing a book in a field which is witnessing rapid progress is that it may become out of date. This book is impressively up to date and many of the authors have included data which were unpublished at the time of going to press. I will continue to find the book useful for a number of years because of its breadth and the chapters which concentrate on areas I am less familiar with. I recommend this book to those interested in the molecular mechanisms of dementia-I will be reading many sections again.

DAVID C RUBINSZTEIN

Genetic Selection through Reproduction Technology. State of the Art and Implications. Editors S Webb, B Durston, D Moore. Australia: Health Department of Western Australia. 1996. ISBN 0-37098379.

This collection of five papers comprises the proceedings of a day long seminar held in Western Australia in 1994, ostensibly for non-scientists. It describes the latest developments in reproductive technology together with the genetic techniques which are being applied to the field, with the aim of enabling the community at large to engage in the debate about the social and ethical implications. We have been grappling with the ramifications of mid-trimester prenatal diagnosis for many years; now there is the immediate possibility of preimplantation genetic testing and selection which raise additional issues. The papers are short or very short; together they occupy less than 30 pages. The first is a sound "no nonsense" explanation of exactly what scientists are trying to achieve by these techniques and what they are not attempting to do. It is a pity the author of the last paper 